\title{
Effect of carbonization on wood anatomy of three Fabaceae species from an Araucaria forest stand in Southern Brazil
}

\author{
Efecto de la carbonización en la anatomía de la madera de tres especies \\ de Fabaceae del Bosque de Araucaria, sur de Brasil
}

\author{
Ângela Maria Stüpp a , Helena Cristina Vieira a , Polliana D'Angelo Rios ${ }^{\text {b, }}$ \\ Graciela Inés Bolzon de Muñiz ${ }^{\mathrm{c}}$, Silvana Nisgoski ${ }^{\text {c* }}$
a Federal University of Paraná, Av. Pref. Lothário Meissner, 632, Jardim Botânico, 80.210-170, Curitiba, PR, Brazil, angela.stupp@ufpr.br, helenavieira@ufpr.br
${ }^{b}$ University of Santa Catarina State, Forest Engineering Course, Av. Luiz de Camões, 2090, bairro Conta Dinheiro, 88520-000 Lages, SC, Brazil, a2pdr@cav.udesc.br \\ *Corresponding author: ${ }^{\mathrm{c}}$ Federal University of Paraná, Forest Engineering and Technology Department, \\ Laboratory of Wood Anatomy and Quality, Av. Pref. Lothário Meissner, 632, Jardim Botânico, 80.210-170, \\ Curitiba, PR, Brazil, graciela.ufpr@gmail.com, silvana.ufpr@gmail.com
}

\begin{abstract}
SUMMARY
The aim of this study was to measure and compare some anatomical elements of wood and charcoal of Inga vera, Machaerium paraguariense and Muellera campestris to support identification of the materials seized by regulatory authorities. For each species, three trees were analyzed. After wood evaluation, all samples (moisture content of $12 \pm 1 \%$ ) were wrapped in aluminum foil and carbonized in a muffle furnace for 8 hours with final temperature of $450{ }^{\circ} \mathrm{C}$ and a heating rate of $1.66{ }^{\circ} \mathrm{C} / \mathrm{min}$. The number of measurements was based on 30 readings regarding tangential diameter and vessel density, along with frequency, height and width of rays (in micrometers). After carbonization, changes in cell dimensions and different behavior were observed in the Fabaceae species evaluated. In all species, vessel diameter declined; vessel density decreased in Inga vera and increased in the other species; ray height decreased in Inga vera and Muellera campestris, and increased in Machaerium paraguariense; and ray width and frequency increased in all species. We concluded that due to the conservation of wood anatomical structures after carbonization, the inclusion of this species in a database would be effective to support efforts to control deforestation in the south of Brazil.
\end{abstract}

Key words: Inga vera, Machaerium paraguariense, Muellera campestris, anatomical characteristics, charcoal.

\section{RESUMEN}

El objetivo de este estudio fue medir y comparar algunos elementos anatómicos de madera y carbón vegetal de Inga vera, Machaerium paraguariense y Muellera campestris con el fin de apoyar la identificación de los materiales incautados por las autoridades reguladoras. Para cada especie, se analizaron tres árboles. Después de la evaluación de la madera, todas las muestras (contenido de humedad de $12 \pm 1 \%$ ) se envolvieron en papel de aluminio y se carbonizaron en un horno de mufla durante 8 horas con una temperatura final de $450{ }^{\circ} \mathrm{C}$ y una velocidad de calentamiento de $1,66^{\circ} \mathrm{C} / \mathrm{min}$. El número de mediciones se basó en 30 lecturas con respecto al diámetro tangencial y densidad de los vasos, junto con frecuencia, altura y ancho de los radios (en micrómetros). Después de la carbonización, se observaron cambios en las dimensiones celulares y diferentes comportamientos en las especies de Fabaceae evaluadas. En todas las especies, el diámetro del vaso disminuyó; la frecuencia de los vasos disminuyó en Inga vera y aumentó en otras especies; la altura de los radios disminuyó en Inga vera y Muellera campestris, y aumentó en Machaerium paraguariense; y el ancho y la frecuencia de los radios aumentaron en todas las especies. Concluimos que debido a la conservación de las estructuras anatómicas de la madera después de la carbonización, la inclusión de esta especie en una base de datos sería efectiva para apoyar los esfuerzos para controlar la deforestación en el sur de Brasil.

Palabras clave: Inga vera, Machaerium paraguariense, Muellera campestris, características anatómicas, carbón vegetal.

\section{INTRODUCTION}

Charcoal is an important raw material for iron and steel making. A potential problem is identification of its origin, which can be from planted forests or illegal wood from native forests (Gonçalves and Schell-Ybert 2012). Sometimes illegal logging is hidden by making charcoal because carbonization makes it harder to identify species. Additiona- 
1ly, charcoal from native wood is often mixed, for example, with charcoal from Eucalyptus L'Hér., a species planted for charcoal production. On this basis, it is necessary to know which anatomical changes that occur during carbonization are related to each species. In general, qualitative characteristics remain unchanged, while some variations occur in dimensions and frequency of vessels and rays (Gonçalves et al. 2012, Gonçalves and Scheel-Ybert 2016). Similarly, Osterkamp et al. (2018) reported that during carbonization, chemical and physical processes occur that result in changes in wood cell dimensions, although general anatomical characteristics remain without major alterations. Therefore, based on wood anatomy, it is possible to distinguish most species after burning (Muñiz et al. 2012b).

Literature reports wood and charcoal anatomy for some species in Brazil, such as macro or microscopic description of Copaifera cf. langsdorfii Desf. and Dipteryx odorata (Aubl.) Willd (Nisgoski et al. 2012); Cedrelinga cateniformis (Ducke) Ducke and Enterolobium schomburgkii (Benth.) Benth. (Muñiz et al. 2012a); Pouteria macrophylla (Lam.) Eyma and Micropholis guianensis (A.DC.) Pierre (Muñiz et al. 2013); Byrsonima spicata (Cav.) DC., Calophyllum brasiliense Cambess., Cecropia sciadophylla Mart., Cochlospermum orinocense (Kunth) Steud. and Schefflera morototoni (Aubl.) Maguire et al. (Nisgoski et al. 2014); Brosimum acutifolium Huber, Ficus citrifolia Mill., Hyeronima laxiflora (Tul.) Müll. Arg. and Sapium glandulatum (Vell.) Pax. (Nisgoski et al. 2015); Anacardiaceae species (Gonçalves and Scheel-Ybert 2016); Mimosa scabrella Benth., Miconia cinnamomifolia (DC.) Naudin, Cecropia glaziovii Snethl, Hyeronima alchorneoides Allemão and Pera glabrata (Schott) Baill. (Carvalho et al. 2017); and angelim species (Muñiz et al. 2016); besides 80 species described in an anthracology atlas (ScheelYbert and Gonçalves 2017).

The Araucaria forest stands in Santa Catarina State, Brazil, are composed of approximately 925 species, from 439 genera in 116 botanical families (Gasper et al. 2013). One of the most important is the Fabaceae family, with 58 species recorded (Gasper et al. 2013), some with high commercial importance, such as Inga vera Willd. and Muellera campestris (Mart. ex Benth) M. J. Silva et A. M. G. Azevedo (Richter and Dallwitz 2000), while others are listed by the Environmental Ministry as endangered in Brazil, such as 12 species from the genus Inga Mill. and one from Machaerium Pers. (MMA 2014).

Considering the extraordinary biological diversity in Brazil, as well as the difficulties related to the inspection of environmental crimes, a reference collection and database with a large number of samples is necessary to facilitate efficient identification of wood and charcoal by regulatory authorities. The aim of this study was to verify wood and charcoal anatomical characteristics in different radial positions of three Fabaceae species (Inga vera, Machaerium paraguariense Hassl and Muellera campestris) to contribute with information to a database for these species evaluation.

\section{METHODS}

Wood samples from Inga vera, Machaerium paraguariense and Muellera campestris were obtained from trees cut by Brazilian Institute of Environment and Renewable Natural Resources (IBAMA) in a region that is now inundated by a reservoir (San Roque hydroelectric plant) in Santa Catarina State. For each species, three trees were collected. Specimens of the botanical material were deposited at Lages Herbarium of Santa Catarina State University - LUSC (table 1). The access to the botanical material was registered under the code AF3EDDC with the Genetic Heritage Management Council (CGEN/SISGEN).

For each tree, we selected a disc with no defects at breast height (DBH) for evaluation and wedge obtainability. The material was divided into three samples oriented in anatomical sections (transversal, longitudinal radial, longitudinal tangential), with dimensions of $2 \times 2 \times 2 \mathrm{~cm}$, codified as near pith (next to the pith, though not including it), intermediate (exactly halfway between near bark and near pith) and near bark (in the outermost part of the disc) (figure 1). Radial sampling was done to cover most anatomical variation that can interfere in wood identification, since results will be added to a database for posterior practical application in forest supervision. Samples were from heartwood, transition and sapwood, varying depending on tree diameter. For characterization, samples were smoothed with \#1200 sandpaper.

Wood and charcoal analyses were performed on the same samples. After wood evaluation, all samples (moisture content of $12 \pm 1 \%$ ) were wrapped in aluminum foil and carbonized in a muffle furnace, as described by Muniz et al. (2012b), with final temperature of $450{ }^{\circ} \mathrm{C}$ (two hours at final temperature) and a heating rate of $1.66^{\circ} \mathrm{C}$ $\mathrm{min}^{-1}$, totaling eight hours. Description of wood and charcoal was based on images obtained with a Discovery V12 stereomicroscope (Zeiss) with the Axio Vision Rel. 4.7 software. Charcoal details were observed with a Hitachi

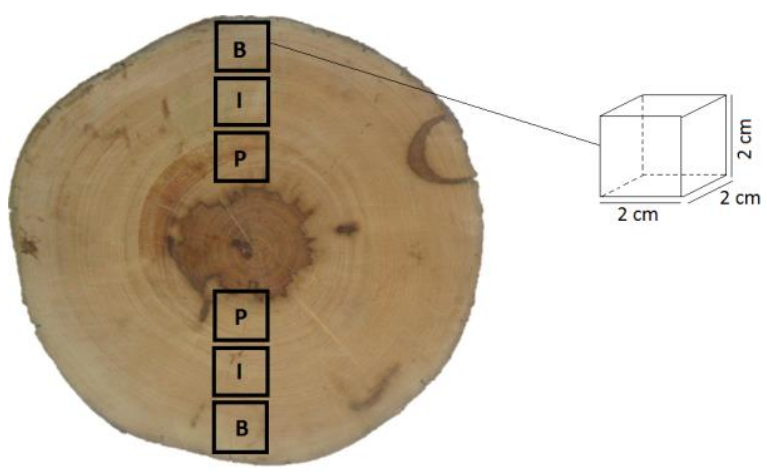

Figure 1. Illustration of sampling disk diagram of Muellera campestris, where B: near bark, I: intermediate, P: near pith.

Diagrama de muestreo en disco de Muellera campestris, donde: B: próximo a la corteza; I: intermedio; P: próximo a la médula. 
Table 1. Species and record numbers.

Especies y números de registro.

\begin{tabular}{|c|c|c|c|}
\hline Species/Record number & $\mathrm{DBH}(\mathrm{cm})$ & Coordinates (WGS84) & Altitude (m) \\
\hline \multicolumn{4}{|l|}{ Inga vera } \\
\hline LUSC 6225 & 26.0 & lat: -27.484728 long: -50.805003 & 701 \\
\hline LUSC 6226 & 18.0 & lat: -27.484378 long: -50.805603 & 851 \\
\hline LUSC 6227 & 17.5 & lat: -27.484228 long: -50.805753 & 731 \\
\hline \multicolumn{4}{|l|}{ Machaerium paraguariense } \\
\hline LUSC 6243 & 18.3 & lat: -27.489997 long: -50.805392 & 734 \\
\hline LUSC 6244 & 12.9 & lat: -27.489997 long: -50.805417 & 734 \\
\hline LUSC 6245 & 11.0 & lat: -27.490006 long: -50.805433 & 734 \\
\hline \multicolumn{4}{|l|}{ Muellera campestris } \\
\hline LUSC 6237 & 31.2 & lat: -27.496892 long: -50.810606 & 692 \\
\hline LUSC 6238 & 25.1 & lat: -27.497081 long: -50.810536 & 696 \\
\hline LUSC 6239 & 15.0 & lat: -27.483572 long: -50.808342 & 740 \\
\hline
\end{tabular}

TM-1000 tabletop scanning electron microscope (SEM) directly from the material, without coating. The description of the anatomical elements of wood and charcoal samples followed procedures from International Association of Wood Anatomists (IAWA, 1989) and 30 measurements were made for tangential diameter and vessel density, as well as frequency, height and width of rays (dimensions in micrometers).

A statistical analysis was performed considering the kind of material (wood or charcoal) and different positions in the disk (near bark, intermediate, near pith), resulting in a $2 \times 3$ factorial analysis. Differences in data between wood and charcoal were evaluated by the Scott-Knott test at $95 \%$ probability, using the Sisvar software.

\section{RESULTS}

Qualitative characteristics. Inga vera. In wood samples, growth ring boundaries were distinguished by differences in fiber zones. Vessels: diffuse porosity, solitary vessels $(68$ $\%$ ) and in radial multiples $2-5(14 \%, 9 \%, 2 \%, 7 \%$, respectively for multiples of 2, 3, 4 and more than 4) (figure 2A), simple perforate plates (figure $2 \mathrm{H}$ ), intervessel pits alternate, gums and other deposits present (figure 2A). Axial parenchyma: lozenge-aliform and confluent (figure 2A). Rays homogeneous, all ray cells procumbent, 1-3 cells wide, not storied (figure 2B). After carbonization, most qualitative characteristics remained intact (figure $2 \mathrm{C}$ ) and it was also possible to observe not storied rays (figure 2D), some ray cells with ruptures (figure 2E) and cells in uniseriate and multiseriate rays (figure 2F). The presence of crystals in axial parenchyma cells was verified (figure $2 \mathrm{G}, \mathrm{H}$ ).
Machaerium paraguariense. In wood samples, growth ring boundaries were little distinguished by fiber zones (figure $3 \mathrm{~A}$ ). Vessels: diffuse porous, mostly solitary vessels ( $84 \%$ ) (figure $3 \mathrm{~A}$ ), in radial multiples $2-4$ present, simple perforate plate (figure $3 \mathrm{H}$ ), alternate intervessel pits. Axial parenchyma: winged-aliform and confluent; diffuse-in-aggregates. Rays: heterogeneous, with procumbent body ray cell and 1-2 rows of square marginal cells, 1-3 cells wide, storied (figure 3B). In charcoal, qualitative characteristics remained, such as solitary vessels (figure $3 \mathrm{C}$ ), storied rays (figure 3D), aliform axial parenchyma (figure 3E), heterogeneous rays (figure $3 \mathrm{G}$ ) and simple perforate plate and alternate intervessel pits (figure $3 \mathrm{H}$ ) and crystals in axial parenchyma cells were also observed (figure 3F).

Muellera campestris. In wood samples, growth ring boundaries were distinct, marked by thin lines from marginal parenchyma (figure 4A). Vessels: diffuse porous with irregular distribution, solitary vessels $(62 \%)$ or in radial multiples $2-4(24 \%, 9 \%, 2 \%$, respectively for multiples of 2, 3 and 4), simple perforate plate, alternate intervessel pits, gums and other deposits present. Axial parenchyma: lozenge-aliform and confluent, vasicentric, unilateral present (figure 4A). Rays: homogeneous, multiseriate and storied (figure 4B). Carbonization resulted in more distinct vessels (figure 4C), more evident irregular distribution, and some contrast in storied rays (figure 4D). It was possible to observe more contrast of axial parenchyma in more detailed images (figure 4E), presence of crystals in axial parenchyma cells (figure 4F), homogeneous rays (figure $4 \mathrm{G}$ ), simple perforate plate (figure $4 \mathrm{H}$ ) and alternate intervessel pits (figure $4 \mathrm{~F}$ ). 
Quantitative characteristics. In wood samples, increase in vessel diameter and decrease in vessel density from near pith to near bark (table 2) were observed. Ray dimensions showed no linear tendency of variation and ray frequency was not influenced by radial position in trunk (table 3 ). In charcoal, changes in structural dimensions were different depending on species characteristics (tables 2 and 3)

\section{DISCUSSION}

Tangential diameter of vessels. In the wood of all species, we observed an increase in vessel diameter from the region of near pith towards near bark, being more accentuated in Muellera campestris. In Inga vera wood, mean vessel diameter was $129 \mu \mathrm{m}$, similar to all species of the genus Inga
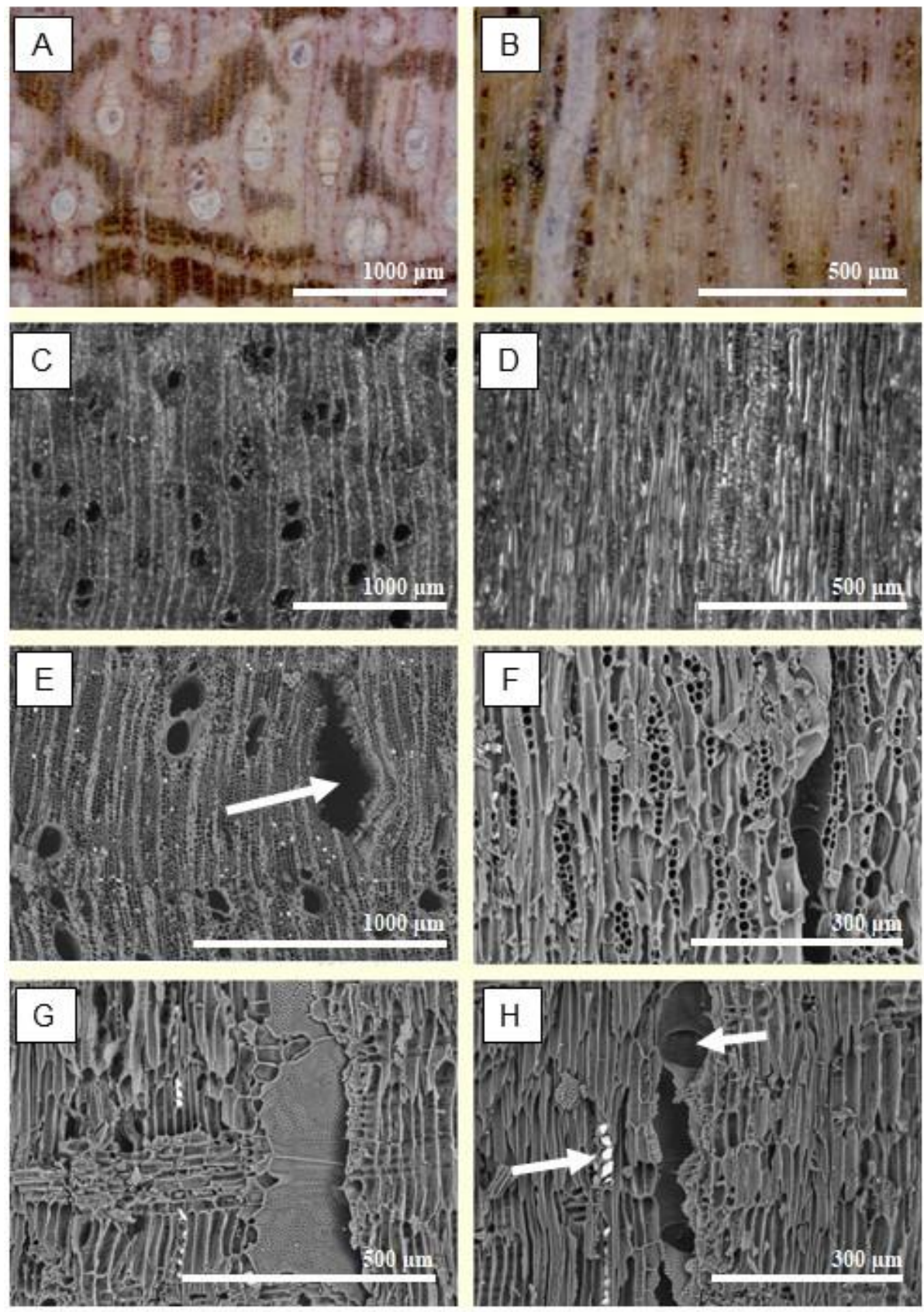

Figure 2. Images of Inga vera wood (A, B) and charcoal (C, D). SEM images of charcoal (E-H). (A, C) transversal section, (B, D, F) tangential section, (E) transversal section, arrow indicates splits in rays; $(\mathrm{G}, \mathrm{H})$ radial section, arrow indicates crystals and simple perforation plate.

Imágenes de la madera (A, B) y carbón (C, D) de Inga vera. MEB imágenes del carbón (E-H). (A, C) sección transversal; (B, D, F) sección tangencial; (E) sección transversal, la flecha indica grietas en los radios; $(\mathrm{G}, \mathrm{H})$ sección radial, la flecha indica cristales y placa de perforación simples. 
published in Inside Wood, along with the study of Ortega et al. (1988), who also analyzed Inga vera. Furthermore, the results of this study are comparable to those reported by Richter and Dallwitz (2000), with values varying from 60-130-200 $\mu \mathrm{m}$, for material collected in Mexico, and those reported by Vieira et al. (2019), with a mean value of $141 \mu \mathrm{m}$. In Machaerium paraguariense wood, mean vessel diameter was $107 \mu \mathrm{m}$, within the range presented in
Inside Wood for the same genus. The results for both $\mathrm{Ma}$ chaerium paraguariense and Muellera campestris wood are proportionate to those of Marchiori et al. (2009), Richter and Dallwitz (2000) and Vieira (2017), although these authors did not ascertain differences from pith to bark.

In charcoal, differences in vessel diameter from near pith to near bark regions were not linear in accordance with position and varied among the species. After carbo-
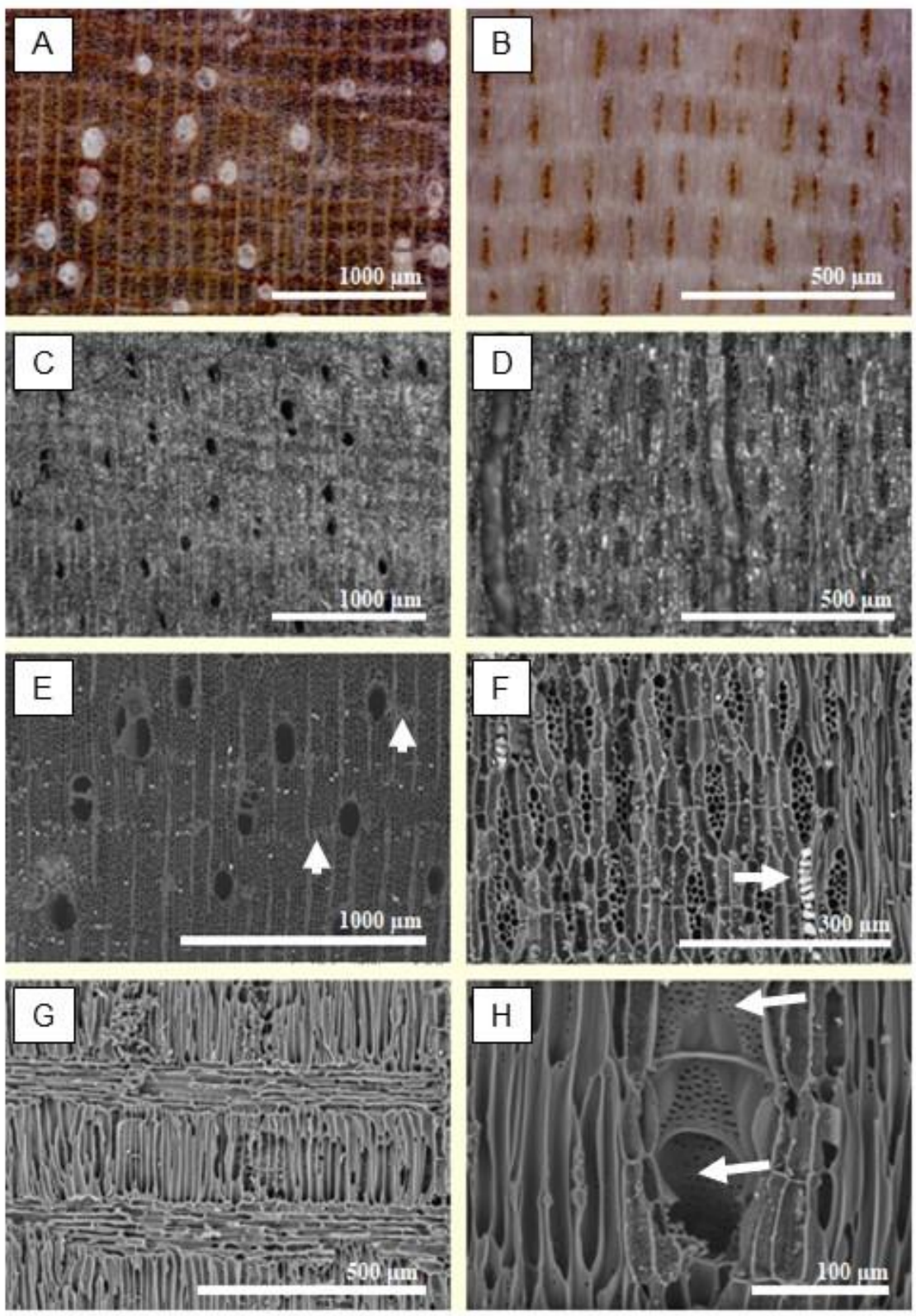

Figure 3. Images of Machaerium paraguariense wood (A, B) and charcoal (C, D). SEM images of charcoal (E-H). (A, C) Transversal section, (B, D) tangential section, (E) transversal section, arrow indicates axial parenchyma; (F) tangential section, arrow indicates crystals in parenchyma cells; $(\mathrm{G}, \mathrm{H})$ radial section, arrow indicates simple perforate plate and intervessel pits.

Imágenes de la madera (A, B) y carbón (C, D) de Machaerium paraguariense. MEB imágenes de lo carbón (E-H). (A, C) Sección transversal; (B, D) sección tangencial; (E) sección transversal, la flecha indica parénquima axial aliforme; (F) sección tangencial, la flecha indica cristales en lo parénquima axial; $(\mathrm{G}, \mathrm{H})$ sección radial, la flecha indica la placa de perforación simple y las punteaduras intervasculares. 
nization, we observed a reduction in vessel diameter for all positions and species. The contraction of cells was more evident in the intermediate position of Machaerium paraguariense $(32.99 \%)$ and less pronounced in the intermediate position of Muellera campestris (14.41\%). Regarding reduction of mean vessel diameter by species after carbonization, Machaerium paraguariense had the most important contraction (32.04 \%) followed by Inga vera $(25.41 \%)$ and Muellera campestris (20.36 \%). Reduction in vessel diameter after carbonization is related to anatomical features, such as the wall thickness of fibers and disposition of axial parenchyma cells, as well as processing conditions such as heating rate. These changes were also reported in other species, such as four Myrtaceae
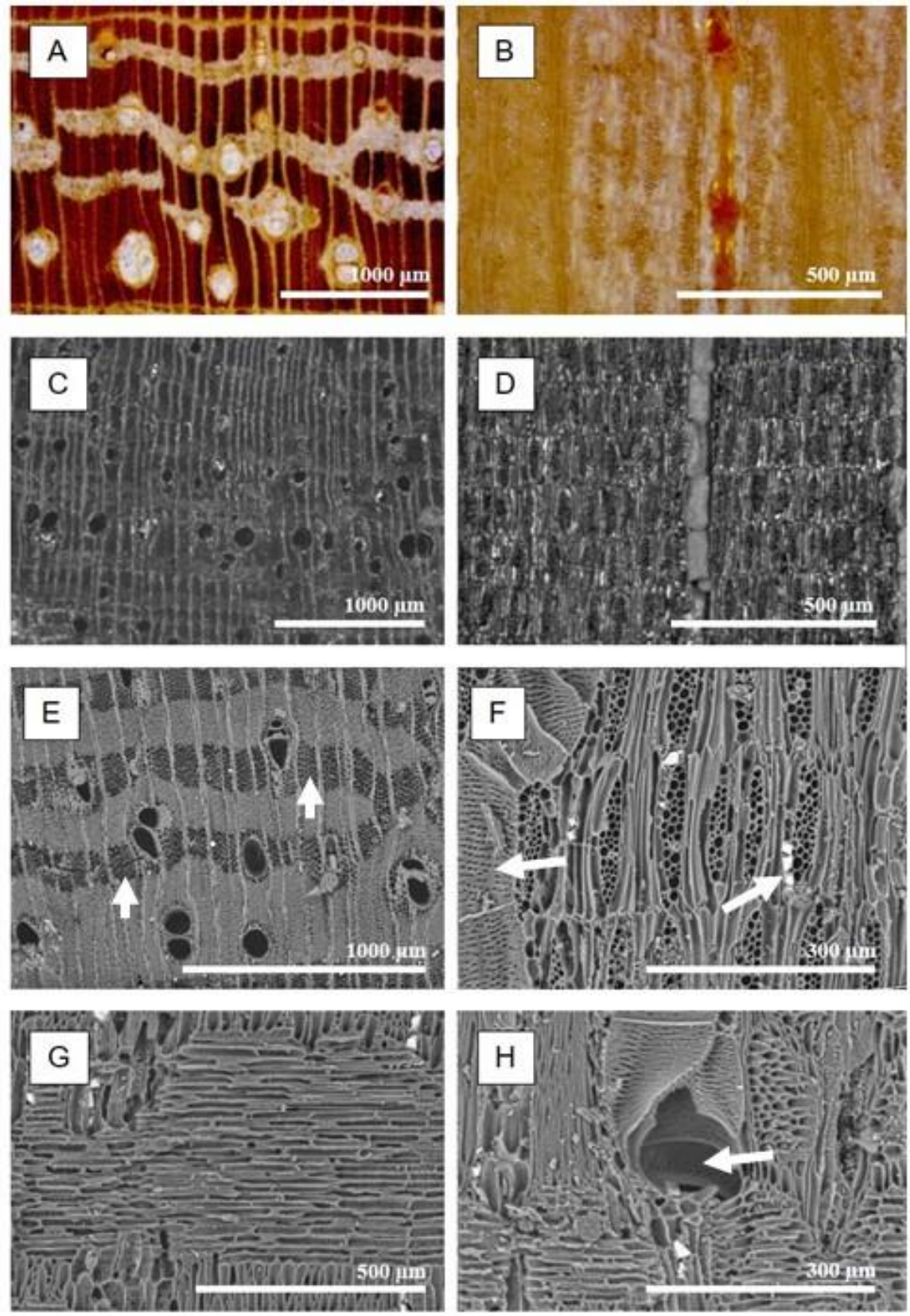

Figure 4. Images of Muellera campestris wood (A, B) and charcoal (C, D). SEM images of charcoal (E-H). (A, C) Transversal section, (B, D) tangential section, (E) transversal section, arrow indicates the axial parenchyma; (F) tangential section, arrow indicates intervessel pits and crystals in parenchyma cells; $(\mathrm{G}, \mathrm{H})$ radial section, arrow indicates simple perforate plate.

Imágenes de la madera (A, B) y carbón (C, D) de Muellera campestris. MEB imágenes de lo carbón (E-H). (A, C) Sección transversal; (B, D) sección tangencial; (E) sección transversal, la flecha indica el parénquima axial; (F) sección tangencial, la flecha indica punteaduras intervasculares y cristales en las células del parénquima axial; $(\mathrm{G}, \mathrm{H})$ sección radial, la flecha indica placa de perforación simples. 
Table 2. Mean values and standard deviation of tangential diameter and vessel density of studied species.

Valores medios y desviación estándar del diámetro tangencial y densidad de los vasos de las especies estudiadas.

\begin{tabular}{|c|c|c|c|c|}
\hline Species & Material & Near Bark & Intermediate & Near Pith \\
\hline \multicolumn{5}{|c|}{ Vessel diameter $(\mu \mathrm{m})$} \\
\hline \multirow{2}{*}{ Inga vera* } & Wood & $139.88 \mathrm{Aa}(21.91)$ & $136.38 \mathrm{Aa}(25.26)$ & $109.17 \mathrm{Ab}(31.92)$ \\
\hline & Charcoal & 106.24 Ba (25.49) & $96.44 \mathrm{Bb}(28.30)$ & $84.18 \mathrm{Bc}(28.96)$ \\
\hline \multirow{2}{*}{ Machaerium paraguariense } & Wood & $119.82 \mathrm{Aa}(23.18)$ & $103.04 \mathrm{Aa}(18.34)$ & $97.85 \mathrm{Ab}(20.69)$ \\
\hline & Charcoal & $81.52 \mathrm{Ba}(22.91)$ & $69.05 \mathrm{Bb}(17.72)$ & $67.34 \mathrm{Bb}(17.55)$ \\
\hline \multirow{2}{*}{ Muellera campestris* } & Wood & $118.27 \mathrm{Aa}(33.21)$ & $105.33 \mathrm{Ab}(23.26)$ & $94.73 \mathrm{Ac}(15.87)$ \\
\hline & Charcoal & $83.90 \mathrm{Bb}(25.53)$ & $90.15 \mathrm{Ba}(23.28)$ & $78.05 \mathrm{Bb}(20.95)$ \\
\hline \multicolumn{5}{|c|}{ Vessel density $\left(\mathrm{n} / \mathrm{mm}^{2}\right)$} \\
\hline \multirow{2}{*}{ Inga vera } & Wood & $6.00 \mathrm{Ab}(3.42)$ & $5.77 \mathrm{Ab}(3.01)$ & $7.58 \mathrm{Aa}(4.35)$ \\
\hline & Charcoal & $5.76 \mathrm{Aa}(2.62)$ & $5.46 \mathrm{Aa}(2.32)$ & $6.49 \mathrm{Aa}(4.49)$ \\
\hline \multirow{2}{*}{ Machaerium paraguariense* } & Wood & $4.18 \mathrm{Bb}(1.69)$ & $5.53 \mathrm{Ba}(2.29)$ & $5.76 \mathrm{Ba}(1.85)$ \\
\hline & Charcoal & $7.64 \mathrm{Aa}(2.70)$ & $7.89 \mathrm{Aa}(2.13)$ & $8.18 \mathrm{Aa}(2.38)$ \\
\hline \multirow{2}{*}{ Muellera campestris* } & Wood & $8.42 \mathrm{Ab}(3.51)$ & $7.61 \mathrm{Ab}(2.71)$ & $10.38 \mathrm{Ba}(3.55)$ \\
\hline & Charcoal & $7.49 \mathrm{Ab}(2.85)$ & $7.84 \mathrm{Ab}(2.59)$ & $12.22 \mathrm{Aa} \mathrm{(5.08)}$ \\
\hline
\end{tabular}

*Species where interaction between material and position was not significant at $95 \%$ probability. For each species, equal letters in means do not present statistical differences by the Scott-Knott test at $95 \%$ probability. Capital letters in column refer to changes after carbonization and small letters are related to radial position in disk (near bark, intermediate, near pith).

species (Stange et al. 2018), in angelim species (Muñiz et al. 2016) and other species from the Fabaceae family (Nisgoski et al. 2012). Another factor that can influence vessel diameter is the possible change in circular shape of cells after carbonization (Gasson et al. 2017).

Vessel density. Decrease in vessel density was observed in wood from the regions near the pith towards the bark, with statistical significance from the intermediate to near pith region, except in Machaerium paraguariense, which had differences between the regions near the bark towards intermediate $(33.3 \%)$. In Inga vera wood, mean vessel density was 6 , similar to the numbers reported by Richter and Dallwitz (2000) and Vieira et al. (2019). In wood from Machaerium paraguariense, the mean value observed was comparable to that reported by Vieira et al. (2019), while for Muellera campestris it was similar to that reported by Marchiori et al. (2009), Richter and Dallwitz (2000) and Vieira (2017).

In charcoal, changes were only observed in Muellera campestris, with decrease in radial direction (33.3\% from near pith towards intermediate and $41.7 \%$ from near pith towards near bark). In other species, there were no differences based on radial position. In a study with Myrtaceae species, Stange et al. (2018) also verified that changes in vessel density were not linear regarding position and oc- curred in accordance with species. Carbonization had little influence on vessel density. Samples from all positions of Machaerium paraguariense and the near pith region of Muellera campestris had significant increase. The highest change was near the bark for Machaerium paraguariense $(82.78 \%)$, although considerable values were noted in the other locations (42.68\% in intermediate and $42.01 \%$ near the pith region). This parameter seems to be influenced by species intrinsic characteristics, since Stange et al. (2018) observed increases in vessel density in all positions after carbonization of four Myrtaceae species.

Regarding mean vessel density, large divergence was observed among the species. A reduction of $7.92 \%$ occurred in Inga vera after carbonization, and increase of 10.60 $\%$ in Muellera campestris and $32.76 \%$ in Machaerium paraguariense were detected. Stange et al. (2018) observed values much higher than for the species studied here with samples of Eugenia pyriformis Cambess (92.3\%), Campomanesia xanthocarpa (Mart.) O. Berg (60.3\%) and Myrcia retorta Cambess (50.7\%). Likewise, the influence of species characteristics on changes in vessel density after carbonization has also been reported in literature, such as for Anacardiaceae (Gonçalves and Scheel-Ybert 2016) and Fabaceae species (Muñiz et al. 2016). The release of volatile matter and formation of some cracks and voids can also interfere in vessel density (Assis et al. 2016). 
Table 3. Mean values and standard deviation of ray dimensions and frequency of studied species.

Valores medios y desviación estándar de las dimensiones y frecuencia de los radios.

\begin{tabular}{|c|c|c|c|c|}
\hline Species & Material & Near bark & Intermediate & Near pith \\
\hline \multicolumn{5}{|c|}{ Ray height $(\mu \mathrm{m})$} \\
\hline \multirow{2}{*}{ Inga vera } & Wood & 189.14 Aa (67.94) & $190.39 \mathrm{Aa}(77.81)$ & $163.39 \mathrm{Ab}(68.56)$ \\
\hline & Charcoal & $165.59 \mathrm{Ba}(60.18)$ & 168.22 $\mathrm{Ba}(55.47)$ & $155.26 \mathrm{Aa}(78.27)$ \\
\hline \multirow{2}{*}{ Machaerium paraguariense } & Wood & 107.41 Aa (21.22) & 109.63 Aa (28.49) & $108.86 \mathrm{Aa}(21.42)$ \\
\hline & Charcoal & $112.05 \mathrm{Aa}(18.31)$ & 111.65 Aa (16.99) & $110.71 \mathrm{Aa}(28.75)$ \\
\hline \multirow{2}{*}{ Muellera campestris } & Wood & 145.84 Aa (33.82) & 137.60 Aa (37.88) & $139.51 \mathrm{Aa}(29.42)$ \\
\hline & Charcoal & $127.58 \mathrm{Ba}(27.96)$ & $116.28 \mathrm{Bb}(22.66)$ & $118.15 \mathrm{Ba}(18.19)$ \\
\hline \multicolumn{5}{|c|}{ Ray width $(\mu \mathrm{m})$} \\
\hline \multirow{2}{*}{ Inga vera* } & Wood & $20.08 \mathrm{Aa}(6.81)$ & $20.32 \mathrm{Aa}(8.46)$ & $15.54 \mathrm{Bb}(5.14)$ \\
\hline & Charcoal & $22.81 \mathrm{Aa}(9.05)$ & $18.95 \mathrm{Ab}(6.32)$ & $23.02 \mathrm{Aa}(16.93)$ \\
\hline \multirow{2}{*}{ Machaerium paraguariense } & Wood & $16.33 \mathrm{Ba}(4.73)$ & $14.13 \mathrm{Bb}(5.18)$ & $15.77 \mathrm{Ba}(5.73)$ \\
\hline & Charcoal & $25.45 \mathrm{Aa}(9.16)$ & $24.73 \mathrm{Aa}(6.04)$ & $25.28 \mathrm{Aa}(7.98)$ \\
\hline \multirow{2}{*}{ Muellera campestris } & Wood & $30.17 \mathrm{Ba}(11.31)$ & $26.69 \mathrm{Ab}(8.07)$ & $24.21 \mathrm{Ab}(9.69)$ \\
\hline & Charcoal & $33.23 \mathrm{Aa}(6.27)$ & $28.74 \mathrm{Ab}(6.32)$ & $25.90 \mathrm{Ac}(7.07)$ \\
\hline \multicolumn{5}{|c|}{ Ray frequency (n/mm) } \\
\hline \multirow{2}{*}{ Inga vera } & Wood & $8.40 \mathrm{Ba}(2.07)$ & $8.46 \mathrm{Ba}(1.93)$ & $8.35 \mathrm{Ba}(2.13)$ \\
\hline & Charcoal & $10.42 \mathrm{Aa}(1.91)$ & $10.62 \mathrm{Aa} \mathrm{(2.07)}$ & $10.31 \mathrm{Aa}(1.76)$ \\
\hline \multirow{2}{*}{ Machaerium paraguariense* } & Wood & $7.54 \mathrm{Ba}(1.24)$ & $7.33 \mathrm{Ba}(1.18)$ & $6.90 \mathrm{Bb}(1.16)$ \\
\hline & Charcoal & $9.20 \mathrm{Aa}(1.27)$ & $9.36 \mathrm{Aa}(1.45)$ & $9.46 \mathrm{Aa}(1.37)$ \\
\hline \multirow{2}{*}{ Muellera campestris* } & Wood & $8.88 \mathrm{Ba}(1.87)$ & $8.64 \mathrm{Ba}(2.01)$ & $8.84 \mathrm{Ba}(1.61)$ \\
\hline & Charcoal & $10.68 \mathrm{Ab}(1.88)$ & $10.82 \mathrm{Ab}(1.70)$ & $12.54 \mathrm{Aa}(1.93)$ \\
\hline
\end{tabular}

*Species where interaction between material and position was not significant at $95 \%$ probability. For each species, equal letters in means do not present statistical differences by the Scott-Knott test at $95 \%$ probability. Capital letters in columns refer to changes after carbonization and small letters are related to radial position in disk (near bark, intermediate, near pith).

Ray height. In wood, no linear pattern was observed in all three species and the variation among positions was from $0.65 \%$ to $5.99 \%$. The highest discrepancy $(14.18 \%)$ was from intermediate towards the near pith of Inga vera. The same species had mean ray height of $181 \mu \mathrm{m}$, lower than the $500 \mu \mathrm{m}$ observed by Richter and Dallwitz (2000). Moreover, in Machaerium paraguariense, mean ray height was $109 \mu \mathrm{m}$, lower than the values observed by Vieira et al. (2019). For Muellera campestris wood, the mean value was $141 \mu \mathrm{m}$, similar to those obtained by Marchiori et al. (2009) in wood from Rio Grande do Sul, and smaller than those observed by Richter and Dallwitz (2000).

In charcoal, reduction in ray height occurred from the near pith towards the intermediate region in Muellera campestris. In other species, there was no influence of position on ray height. Carbonization did not statistically influence ray height in Machaerium paraguariense. For Muellera campestris, all positions presented reduction in ray height from wood to charcoal (12.52 \% near bark, $15.49 \%$ intermediate and $15.31 \%$ near pith), probably as a result of the higher quantity of parenchyma cells in comparison to the other two species. In Inga vera, only in the near pith region were there no substantial changes in dimension, while for other positions, reductions of $12.45 \%$ in the near bark position and $11.64 \%$ for intermediate region were observed. According to Muñiz et al. (2012), rays are laterally connected to fibers, which limit rays movement, since the contraction of the fibers in the axial direction is small during the carbonization process. On the other hand, Stange et al. (2018) described reduction of ray height in Campomanesia xanthocarpa and Eugenia pyriformis and increase in Myrcia retorta species in all radial positions.

With regard to mean ray height values by species, a contrast was observed after carbonization, with reduction of $9.69 \%$ in Inga vera and $14.44 \%$ in Muellera campestris, and with increase of $2.62 \%$ in Machaerium pa- 
raguariense. Different behavior has also been reported in literature, associated with ruptures of cells due to cell wall expansion, which can vary in accordance with fiber or parenchyma expansion (Gonçalves et al. 2012, Muñiz et al. 2012, Nisgoski et al. 2019). Ruptured rays were verified in some eucalyptus species (Gonçalves et al. 2014) and reductions in ray height after carbonization have been described, for example, in Dipteryx odorata (Nisgoski et al. 2012), Diplotropis purpurea (Rich.) Amshoff (Muñiz et al. 2016), Eugenia pyriformis, Campomanesia xanthocarpa and Plinia peruviana (Poir.) Govaerts (Stange et al. 2018). Increase in ray height has been found in Cedrelinga catenaeformis (Muñiz et al. 2012a), Ocotea porosa (Nees et Mart.) Barroso (Nisgoski et al. 2014) and Myrcia retorta (Stange et al. 2018).

Ray width. For ray width, a difference was observed in wood from near pith towards near bark, nevertheless there was no pattern in all species. Significant increase was observed from near pith towards the bark region in Inga vera $(23.52 \%)$. The same pattern was also noted from near pith to intermediate $(9.29 \%)$ and to near bark $(11.54 \%)$ region in Muellera campestris. In Machaerium paraguariense, the intermediate region had thinner rays than those of the near pith (10.40\%) and near bark regions (13.47\%). Stange et al. (2018) also observed divergence in this characteristic in the radial position of Myrtaceae species, with predominance of thinner rays in the near pith region.

In charcoal, there was no difference in ray width concerning sample position in Machaerium paraguariense. Increase was observed from near pith towards near bark in Muellera campestris (22.06 \%). In Inga vera charcoal, ray width was lower in the intermediate position when compared to the other regions (16.92\% near bark and $17.68 \%$ near pith). After carbonization, there was significant increase in ray width in all samples of Machaerium paraguariense, with variation of $35.83 \%$ for near bark, $42.86 \%$ in intermediate wood and $37.62 \%$ for near pith. Correspondingly, the same behavior was observed for near pith $(32.49 \%)$ and near bark (11.97 \%) in Inga vera and near bark in Muellera campestris (10.14 \%). According to Stange et al. (2018), these results may be related to ruptures that occur due to the expansion of cell walls.

Regarding mean ray width values, increase was observed in all species, varying from $8.27 \%$ in Muellera campestris to $38.77 \%$ in Machaerium paraguariense, and intermediate in Inga vera, with $17.07 \%$ increase. These differences can be the result of multiseriate and uniseriate ray percentage. Literature reports divergent behavior of species related to chemical changes in substances stored in parenchyma cells: decrease in ray width in the Fabaceae family was reported in Enterolobium schomburgkii (Muñiz et al. 2012a), Dipteryx odorata (Nisgoski et al. 2012) and Parkia pendula (Muñiz et al. 2016); while increase in ray width was observed in Cedrelinga catenaeformis (Muñiz et al. 2012a), Hymenolobium petraeum and Va- tairea paraensis (Muñiz et al. 2016). Moreover, increase in ray width was observed in Cerrado (savanna) species (Gonçalves et al. 2012) and Myrtaceae species (Stange et al. 2018).

Ray frequency. Ray frequency in wood, in general, was not influenced by radial position in the trunk. Only the near pith region of Machaerium paraguariense had a value lower (12.5\%) than that presented by the other regions. In Inga vera wood, mean ray frequency was $8 / \mathrm{mm}$, in the range reported by Richter and Dallwitz (2000) and Vieira et al. (2019). In Machaerium paraguariense, mean ray frequency was $7 / \mathrm{mm}$, higher than what was observed by Vieira et al. (2019). For Muellera campestris, 9 rays / mm were observed, lower than what was reported by Marchiori et al. (2009), who found mean ray frequency of 12 (10-15) in wood from Rio Grande do Sul, and similar to the value obtained by Vieira (2017).

In charcoal, ray frequency showed reduction of $15.38 \%$ from near pith towards the intermediate/near bark region in Muellera campestris, and $9.09 \%$ from intermediate to near pith and near bark of Inga vera. In all species and positions, carbonization affected ray frequency. Regarding mean values, ray frequency increased by similar values: $24.35 \%$ in Inga vera, $29.12 \%$ in Muellera campestris and $28.94 \%$ in Machaerium paraguariense. In other species of the Fabaceae family, Muñiz et al. (2016) verified significant increase in ray frequency in Diplotropis purpurea, Hymenolobium petraeum and Vatairea guianensis. Different behavior was observed by Ávila et al. (2017) regarding mass loss and cell contraction after carbonization, attributed to the influence of intra-specific and ecological characteristics.

\section{CONCLUSIONS}

The changes in cell dimensions caused by the carbonization process were confirmed. In all species, the vessel diameter decreased; vessel density decreased in Inga vera, though it increased in the other species; ray height decreased in Inga vera and Muellera campestris, however increased in Machaerium paraguariense; and ray width and frequency increased in all species.

Despite the alterations resulting from carbonization, cell arrangement and type were not influenced, therefore the inclusion of these species in a database would be effective to support efforts to control deforestation in the south of Brazil. Charcoal anatomy can be applied for species characterization, and in comparison, with reference data, can support illegal logging control.

\section{ACKNOWLEDGMENTS}

The authors thank Coordenação de Aperfeiçoamento de Pessoal de Nível Superior - Brazil (CAPES) - Finance Code 001, and Programa Uniedu Pós-Graduação - Santa Catarina-Brazil. 


\section{REFERENCES}

Assis MR, L Brancheriau, A Napoli, PF Trugilho. 2016. Factors affecting the mechanics of carbonized wood: literature review. Wood Science and Technology 50(3): 519-536. DOI: https://doi.org/10.1007/s00226-016-0812-6

Ávila A, C Giongo, R Scheel-Ybert. 2017. Anatomia do lenho carbonizado de 10 espécies nativas da planície costeira do Rio Grande do Sul - subsídio a pesquisas arqueobotânicas e paleoecológicas. Cadernos do LEPAARQ(UFPEL) 14(27): 482511. DOI: http://dx.doi.org/10.15210/lepaarq.v14i27.9661

Carvalho AF de, MA Brand, S Nisgoski, GIB Muñiz, G Friederichs, LC Kuster, TS Santos. 2017. Anatomia do carvão oriundo de cinco espécies comercializadas no estado de Santa Catarina. Ciência da Madeira 8(3): 158-167. DOI: http:// dx.doi.org/10.15210/cmad.v8i3.7542

Gasper AL, L Sevegnani, AC Vibrans, M Sobral, A Uhlmann, DV Lingner, MJ Rigon Júnior, M Verdi, AS Santos, S Dreveck, A Korte. 2013. Inventário florístico florestal de Santa Catarina: espécies da Floresta Ombrófila Mista. Rodriguésia 64(2): 201-210. DOI: http://dx.doi.org/10.1590/S2175$\underline{78602013000200001}$

Gasson P, C Cartwright, CL Dias Leme. 2017. Anatomical changes to the wood of Croton sonderianus (Euphorbiaceae) when charred at different temperatures. IAWA Journal 38: 117-123. DOI: https://doi.org/10.1163/22941932-20170161

Gonçalves TAP, AW Ballarin, S Nisgoski, GIB de Muñiz. 2014. A contribution to the identification of charcoal origin in Brazil I - Anatomical characterization of Corymbia and Eucalyptus. Maderas. Ciencia y Tecnología 16(3): 323-336. DOI: http:// dx.doi.org/10.4067/S0718-221X2014005000025

Gonçalves TAP, CR Marcati, R Scheel-Ybert. 2012. The effect of carbonization on wood structure of Dalbergia violaceae, Stryphnodendron polyphyllum, Tapirira guianensis, Vochysia tucanorum and Pouteria torta from the Brazilian Cerrado. IAWA Journal 33(1): 73-90.

Gonçalves TAP, R Scheel-Ybert. 2012. Contra o carvão ilegal: estudo da anatomia da madeira pode ajudar a salvar florestas nativas. Ciência Hoje 292: 74-76.

Gonçalves TAP, R Scheel-Ybert. 2016. Charcoal anatomy of Brazilian species. I. Anacardiaceae. Anais da Academia Brasileira de Ciências 88(3 Suppl.): 1711-1725. DOI: http://dx.doi. org/10.1590/0001-3765201620150433

IAWA Committee (International Association of Wood Anatomists). 1989. List of microscopic features for hardwood identification. IAWA Bulletin 10(3): 219-332.

Marchiori JNC, GIB Muñiz, SR Santos. 2009. Madeiras do Rio Grande do Sul: 1-Descrição microscópica de 33 espécies nativas. Vol. 1. Anaterra: Santa Maria. $80 \mathrm{p}$.

MMA (Ministério do Meio Ambiente, BR). 2014. Lista Nacional Oficial de Espécies da Flora Ameaçadas de Extinção. Ministério do Meio Ambiente. Portaria MMA n ${ }^{\circ} 443$.

Muñiz GIB, S Nisgoski, RF França, FZ Schardosin. 2012a. Anatomia comparativa da madeira e carvão de Cedrelinga catenaeformis Ducke e Enterolobium schomburgkii Benth. para fins de identificação. Scientia Forestalis 40(94): 291-297.

Muñiz GIB, S Nisgoski, FZ Schardosin, RF França. 2012b. Anato- mia do carvão de espécies florestais. Cerne 18(3): 471-477.

Muñiz GIB, RF França, AE Fiorese, S Nisgoski. 2013. Análisis de la estructura anatómica de la madera y del carbón de dos especies de Sapotaceae. Maderas. Ciencia y Tecnología 15(3): 311-320. DOI: http://dx.doi.org/10.4067/S0718221X2013005000024

Muñiz GIB, ME Carneiro, FRR Batista, FZS Schardosin, S Nisgoski. 2016. Wood and charcoal identification of five species from the miscellaneous group known in Brazil as "angelim" by near-ir and wood anatomy. Maderas. Ciencia y Tecnología 18(3): 505-522. DOI: http://dx.doi.org/10.4067/S0718$\underline{221 X 2016005000045}$

Nisgoski S, GIB Muñiz, RF França, FRR Batista. 2012. Anatomia do lenho carbonizado de Copaifera cf. langsdorfii Desf. e Dipteryx odorata (Aubl.) Wild. Ciencia da Madeira 3(2): 66-79.

Nisgoski S, WLE Magalhães, FRR Batista, RF França, GIB Muñiz. 2014. Anatomical and energy characteristics of charcoal made from five species. Acta Amazonica 44(3): 367-372. DOI: http://dx.doi.org/10.1590/1809-4392201304572

Nisgoski S, GIB Muñiz, SR Morrone, FZ Schardosin, RF França. 2015. NIR and anatomy of wood and charcoal from Moraceae and Euphorbiaceae species. Ciência da Madeira 6(3): 183-190. DOI: http://dx.doi.org/10.15210/cmad.v6i3.7140

Nisgoski S, HC Vieira, TAP Gonçalves, CM Afonso, GIB Muñiz. 2019. Impact of carbonization parameters on anatomic aspects and near infrared spectra of three species from Mozambique. Wood Science and Technology 53(6): 1373-1394. DOI: https://doi.org/10.1007/s00226-019-01134-8

Ortega F, L Gerrero, T Carnona, C Córdoba. 1988. Angiospermas Arboreas de Mexico. Núm 1. Anatomica de la madera de veintiocho especies de Cosautlan de Carvajal. La Madera y su Uso 19. Instituo Nacional de Investigaciones sobre Recursos Bioticos.

Osterkamp IC, DM Lara, TAP Gonçalves, M Kauffmann, E Périco, S Stülp, NTG Machado, D Uhl, A Jasper. 2018. Changes of wood anatomical characters of selected species of Araucaria during artificial charring: implications for paleontology. Acta Botanica Brasilica 32(2): 198-211. DOI: http://dx.doi. org/10.1590/0102-33062017abb0360

Richter HG, MJ Dallwitz. 2000 onwards. Commercial timbers: descriptions, illustrations, identification, and information retrieval. Version: $7^{\text {th }}$ August 2018. Accessed 10 may 2018. Available at http://delta-intkey.com

Scheel-Ybert R, TAP Gonçalves. 2017. Primeiro atlas antracológico de espécies brasileiras. Rio de Janeiro, Brazil. Museu Nacional. 230 p.

Stange R, HC Vieira, PDA Rios, S Nisgoski. 2018. Wood and charcoal anatomy of four Myrtaceae species. Cerne 24(3): 190200. DOI: http://dx.doi.org/10.1590/01047760201824032552

Vieira HC. 2017. Anatomia da madeira de espécies arbóreas da Floresta Ombrófila Mista. Dissertação Mestrado em Engenharia Florestal, Lages, Santa Catarina, Brasil. Universidade do Estado de Santa Catarina, UDESC. 204p.

Vieira HC, PDA Rios, TMGQM Santos, ABD Cunha, MA Brand, D Danielli, JB Florez, R Stange, R Buss, P Higuchi. 2019. Agrupamento e caracterização anatômica da madeira de espécies nativas da Floresta Ombrófila Mista. Rodriguésia 70: e04382017. DOI: http://dx.doi.org/10.1590/2175-7860201970038 